\title{
Toxicological evaluation of the leaves of Guiera senegalensis (J.F. Gme), Cassia occidentalis (Linn), and Ziziphus mauritiana (Lam)
}

\author{
Tajudeen Yahaya ${ }^{1 *}$, Kasimu Shehu', Hanan Isah', Esther Oladele ${ }^{2}$ and Ufuoma Shemishere ${ }^{3}$
}

\begin{abstract}
Background: There is a renewed global interest in plant-based medicine in the last few decades as a result of affordability and efficacy of the form of medicine. However, the safety of many medicinal plants and plant preparations has not been determined. To this end, this study determined the safety of the methanol extracts of the leaves of Guiera senegalensis, Cassia occidentalis, and Ziziphus mauritiana, which are plants commonly used in plant medicine in Africa.

Results: Phytochemistry of the plants' extracts showed alkaloids were the most abundant phytochemical in the extracts, followed by tannins, saponins, flavonoids, and glycosides, respectively. All the rats behaved normally at doses up to $2000 \mathrm{mg} \mathrm{kg}^{-1}$, while at $3000 \mathrm{mg} \mathrm{kg}^{-1}$, rats in C. occidentalis group developed breathing problems. At $5000 \mathrm{mg} \mathrm{kg}^{-1}$, C. occidentalis group showed convulsion, whereas Z. mauritiana and G. senegalensis rats displayed temporary weakness. After 60-day dosing, significant differences $(p<0.05)$ were observed in the liver enzymes (ALP, AST, ALT, TP, and ALB) of most of the test rats compared with the control. Kidney function test showed the $\mathrm{Na}^{+}, \mathrm{K}^{+}$, $\mathrm{Cl}^{-}$, urea, and creatinine of the test rats were reduced compared with the control, but only significant $(p<0.05)$ in a few of the parameters. Fatty metamorphosis, lymphocytic infiltration, and karyorrhexis were observed in the liver tissues of the treated rats, but not in the control.
\end{abstract}

Conclusion: These results show the plants are nontoxic at moderate doses, but could be injurious at high doses or if taken repeatedly for an extended period.

Keywords: Alkaloids, Creatinine, Phytochemical, Toxicity, Urea, Guiera senegalensis

\section{Background}

Several scientific investigations and, to some extent, clinical trials have emphasized the importance of plants in the treatment of many diseases. Most developing nations, especially in Africa, rely on traditional medicines for different health needs as a result of their availability [1]. It is estimated that about $80 \%$ of the world's population, mostly in the developing countries, depend on plant medicines $[2,3]$. The use of plant medicines dates back to several thousands of years [4], but the form of

\footnotetext{
* Correspondence: yahayatajudeen@gmail.com; yahaya.tajudeen@fubk.edu.ng 'Department of Biology, Federal University Birnin Kebbi, Birnin Kebbi PMB 1157, Nigeria

Full list of author information is available at the end of the article
}

medicine practically vanished with the evolution of modern medicine and synthetic drugs in the eighteenth century. However, plant medicine is currently on the rise because many medicinal plants have been discovered to contain several bioactive compounds employed in pharmaceutical industries [4]. Other reasons for the renewed interest in plant medicines are because they are cost effective and simple to prepare [5, 6]. Plant medicine has become so prominent that many drugs in current use contain bioactive substances of plant origin [7]. It is estimated that about $25 \%$ of all modern medicines are derived from plants $[7,8]$.

The renaissance in plant-based medicine has opened up a lot of job opportunities worldwide. Particularly, in 
Nigeria, it has lifted many people out of poverty by providing daily living to the practitioners, marketers, and other classes of workers. Plant-based medicine outfits and shops are springing up steadily in the country, engaging able-bodied men and women, thereby reducing the menace of unemployment ravaging the country. Moreover, it has helped cure some ailments which have defied conventional treatment methods. Plant-based medicine has gained so much prominence and acceptability in Nigeria that at a point the country proposed to establish a university of alternative medicine. This was conceived to boost the activities of the industry and integrate it fully into the country's health care delivery system.

The popularity of plant medicine in Nigeria can be attributed partly to the abundance of plant species with medicinal properties in the country. Of the numerous medicinal plants native to Nigeria, Guiera senegalensis, Cassia occidentalis, and Ziziphus mauritiana are frequently used in the northern part of the country. G. senegalensis is called Sabara by Hausa and other tribes in northern Nigeria. The plant contains abundant phenolic and flavonoidal compounds and is often used in the region to treat diarrhea and fever as well as increase milk production in lactating women $[9,10]$. C. occidentalis, called Sanga-Sanga in northern Nigeria, has alkaloids, phlobatannins, tannins, flavonoids, saponins, terpenes, etc., and is used to treat leg pains, swollen feet, and hepatitis, among others [10-12]. Z. mauritiana is called Magarya in Hausa and is rich in alkaloids, flavonoids, tannins, steroids, and saponins [13]. Its leaves are frequently used to treat wounds, infection, fever, liver diseases, and asthma [13, 14]. However, the safety of these plants has not been established. Though some studies had been carried out in this regard, their results are inconsistent. For example, while Nuhu and Aliyu [11] reported hypoproteinemia and elevated liver enzymes in rats fed with extracts of C. occidentalis, Silva et al. [15] found no effects of short- and long-term administration of $C$. occidentalis in treated rats. Vashishtha et al. [16] also linked the consumption of C. occidentalis beans to the outbreak of the hepatomyoencephalopathy syndrome among children in western Uttar Pradesh. Therefore, a study aimed at determining the safe doses of these plants becomes imperative, so as to prevent untended fatalities. To this end, this study evaluated the toxicity of the leaves of Guiera senegalensis, Cassia occidentalis, and Ziziphus mauritiana.

\section{Methods}

\subsection{Source of test animal and management}

One hundred and forty (140) experimental rats (Rattus norvegicus) of both sexes and age 60 days with a mean weight of $210 \pm 10 \mathrm{~g}$ were employed for this study. The rats were kept in metal cages in a wellventilated animal house with five rats placed in each cage and maintained at room temperature $\left(32 \pm 2{ }^{\circ} \mathrm{C}\right)$. The rats had free access to water and rodent pellet feeds from the Vital Feeds Limited, Lagos, Nigeria.

\subsection{Plant materials and extraction of bioactive compounds}

Fresh leaves of Guiera senegalensis, Cassia occidentalis, and Ziziphus mauritiana were collected around Kalgo, Birnin Kebbi, Nigeria, in August 2018. The plants were identified by a taxonomist in the Department of Plant Science and Biotechnology, Kebbi State University of Science and Technology, Aliero. Samples of the authenticated plants with voucher numbers V.N 48, V.N 71, and V.N 258 for G. senegalensis, C. occidentalis, and $Z$. mauritiana, respectively, were kept in the herbarium section of the department. The plant materials were washed gently to remove impurities and air-dried under shade to a constant dry weight. The dried leaves were milled into fine powder using a laboratory grinder manufactured by TENCAN (model no: XQM-(20-100). About 100, 50, and $100 \mathrm{~g}$ powder of $Z$. mauritiana, $C$. occidentalis, and G. senegalensis were soaked in flasks containing 600,300 , and $600 \mathrm{ml}, 98 \%$ methanol, respectively, and were allowed to stand for $24 \mathrm{~h}$. The extracts thus obtained were filtered with muslin cloth, and the solvent (methanol) was removed using a rotary evaporator at $45^{\circ} \mathrm{C}$. The dried extracts were stored in a desiccator before use.

\subsection{Qualitative screening of the extracts}

The qualitative screening of the extracts was done using standard protocols as described by Sofowora [17].

\subsubsection{Test for glycosides}

About $2.5 \mathrm{ml}$ of $50 \% \mathrm{H}_{2} \mathrm{SO}_{4}$ was added to $5 \mathrm{ml}$ of each extract in a test tube, and the mixture was heated in a boiling bath for $15 \mathrm{~min}$. The mixture was allowed to cool and neutralized with $10 \% \mathrm{NaOH}$. About $5 \mathrm{ml}$ of Fehling's solution was added, and the mixture was boiled. A brick-red precipitate was observed, which indicated the presence of glycosides.

\subsubsection{Test for anthraquinones}

The extract $(0.5 \mathrm{~g})$ of each plant was shaken with $10 \mathrm{ml}$ of benzene. The mixture was filtered after which $5 \mathrm{ml}$ of $10 \%$ ammonia solution was added to the filtrate and shaken gently. The presence of a pink, red, or violet color in the ammoniacal (lower) phase indicated the presence of anthraquinones. 


\subsubsection{Test for saponins}

About $0.5 \mathrm{~g}$ of each extract was dissolved in $10 \mathrm{ml}$ of distilled water in a test tube. The test tube was covered tightly and shaken vigorously for $30 \mathrm{~s}$, after which it was allowed to stand for $45 \mathrm{~min}$. The appearance of frothing, which persists on warming, indicated the presence of saponins.

\subsubsection{Test for phlobatanins}

The presence of phlobatanins in the extract was determined using the hydrogen chloride test. The extract $(0.5 \mathrm{~g})$ was dissolved in distilled water and filtered after which the filtrate was boiled with $2 \%$ $\mathrm{HCl}$ solution. A red precipitate revealed the presence of phlobatanins.

\subsubsection{Test for flavonoids}

To a portion of the dissolved extract, a few drops of $10 \%$ ferric chloride solution were added. A green or blue color indicated the presence of flavonoids.

\subsubsection{Test for steroids}

About $0.5 \mathrm{~g}$ of each extract was dissolved in $2 \mathrm{ml}$ acetic anhydride and placed in ice. Sulfuric acid was then carefully added, and a color change from violet to blue and finally green indicated the presence of a steroidal nucleus.

\subsubsection{Test for tannins}

About $0.5 \mathrm{~g}$ of the extract was dissolved in $5 \mathrm{ml}$ of water, followed by a few drops of $10 \%$ ferric chloride. A blueblack, green, or blue-green precipitate indicated the presence of tannins.

\subsubsection{Test for alkaloids}

The presence of alkaloids in the extracts was tested using the Wagner-Dragendorff's test. About $0.2 \mathrm{~g}$ of the extracts was heated with $2 \% \mathrm{H}_{2} \mathrm{SO}_{4}$ for 2 min. The mixture was filtered, and few drops of Dragendorff's reagent were added. An orange-red precipitate showed the presence of alkaloids.

\subsection{Quantitative screening of the extracts}

The levels of the phytochemicals detected in the extracts of the plants during the qualitative screening were estimated using the method of Ajuru et al. [18].

\subsubsection{Estimation of alkaloids}

Five grams of extract of each plant was put in a 250$\mathrm{ml}$ beaker, and $200 \mathrm{ml}$ of $20 \%$ acetic acid in ethanol was added and made to stand for $4 \mathrm{~h}$. The mixture was filtered, and the filtrate was concentrated to one quarter of the original volume using a water bath. Few drops of concentrated ammonium hydroxide were added to the extract until the preparation was complete. The solution was allowed to settle, and the precipitate was collected by filtration and weighed. The weight of the alkaloids obtained was then expressed as a percentage of the raw extract of the plant:

$$
\text { Alkaloids }(\%)=[\text { weight of alkaloids } / \text { weight of raw extract }] \times 100
$$

\subsubsection{Estimation of tannins}

Five grams of each extract was weighed into a 100-ml plastic bottle containing $50 \mathrm{ml}$ of distilled water and shaken for $1 \mathrm{~h}$ in a mechanical shaker. The filtrate obtained was put in a $50-\mathrm{ml}$ volumetric flask and made up to the mark. Then, $5 \mathrm{ml}$ of the filtrate was pipette into a tube and mixed with $3 \mathrm{ml}$ of $0.1 \mathrm{M} \mathrm{FeCl}_{3}$ in $0.1 \mathrm{~N} \mathrm{HCl}$ and $0.008 \mathrm{M}$ potassium ferrocyanide. The absorbance was measured in a spectrophotometer at $120 \mathrm{~nm}$ wavelength within $10 \mathrm{~min}$. A blank sample was prepared, and the color also developed and read at the same wavelength. A standard was prepared using tannic acid to get $100 \mathrm{ppm}$ and measured. The weight was thereafter expressed as a percentage of the raw extract.

\subsubsection{Estimation of flavonoids}

One hundred grams of each plant extract was extracted repeatedly with $100 \mathrm{ml}$ of $80 \%$ aqueous methanol at room temperature. The whole solution was filtered using Whatman filter paper no. $42(125 \mathrm{~mm})$. The filtrate was later transferred into a crucible, evaporated to dryness over a water bath, and weighed and expressed as a percentage of the raw extract.

\subsubsection{Estimation of saponins}

The extracts were ground, and $20 \mathrm{~g}$ was transferred into $200 \mathrm{ml}$ of $20 \%$ ethanol. The suspension produced was heated over a hot water bath for $4 \mathrm{~h}$ with continuous stirring at about $55^{\circ} \mathrm{C}$. The mixture was filtered, and the residue re-extracted with another $200 \mathrm{ml}$ of $20 \%$ ethanol. The combined extracts were reduced to $40 \mathrm{ml}$ over a water bath at about $90^{\circ} \mathrm{C}$. The concentrate was transferred into a 250-ml separator funnel, and $20 \mathrm{ml}$ of diethyl ether was added and shaken vigorously. The aqueous layer was recovered while the ether layer was discarded. The purification process was repeated, and $60 \mathrm{ml}$ of $n$-butanol was added. The combined $n$-butanol extracts were washed twice with $10 \mathrm{ml}$ of $5 \%$ aqueous sodium chloride. The remaining solution was heated in a water bath. After evaporation, the samples were dried in the oven to a constant weight and estimated as a percentage of the raw extract. 


\subsubsection{Estimation of glycosides}

One gram of the extract was macerated in $50 \mathrm{ml}$ of distilled water and filtered. Then, $4 \mathrm{ml}$ of the alkaline picrate solution was added to $1 \mathrm{ml}$ of the filtrate. The mixture was boiled for $5 \mathrm{~min}$, allowed to cool, and weighed and expressed as a percentage of the raw extract.

\subsection{Experimental design}

The toxicity test of methanol extracts of the three plants was determined in two phases. In the first phase, the "Classical $\mathrm{LD}_{50}$ " method described by Trevan [19] was used to establish the range of doses capable of producing toxic effects. Ninety rats were randomly divided into 3 groups containing 30 rats each with a group assigned 1 of the extracts and labeled G. senegalensis, C. occidentalis, and $Z$. mauritiana group, respectively. The thirty rats in each group were subdivided into 5 containing 6 rats each and administered 500, 1000, 2000, 3000, and 5000 $\mathrm{mg} \mathrm{kg}$-1 of the extract, respectively. A control group was equally set up, but rats in this group were not given any extract. The rats were monitored for $72 \mathrm{~h}$, and general toxicities of the extracts were evaluated according to a set of signs determined by Almeida [20].

In the second phase, a new set of 36 rats were distributed equally into 4 groups. Rats in groups 1, 2, and 3 were administered $1000 \mathrm{mg} \mathrm{kg}^{-1}$ extracts of G. senegalensis, C. occidentalis, and Z. mauritiana, respectively, for 60 days. The fourth group was made the control and were not fed any extract. At the end of the treatments, the rats were sacrificed by cervical dislocation after sedating them with chloroform in a tightly covered bell-shaped glass jar. Blood samples were then collected for liver function tests (alanine aminotransferase (ALT), apartatate aminotransferase (AST), alkaline phosphatase (ALP), total protein (TP), and albumin) and kidney function tests (creatinine, urea, $\mathrm{Cl}^{-}, \mathrm{Na}^{+}$, and $\mathrm{K}^{+}$). The livers of the rats were also harvested for histological examination.

\subsection{Blood sample collection procedures}

Blood samples were obtained from the rats based on the method of Hugo and Russel [21]. The rats were sedated with chloroform in a bell-shaped glass jar in the laboratory. Total death was prevented to allow continuous flow of blood for proper blood collection. Each rat was pegged down on a work bench and held firmly with office pins. A surgical blade was used to cut through the chest region of the rats in the dorsal-ventral direction. The blood was then collected from a beating heart using a heparinized capillary tube through capillary action into EDTA bottle. EDTA serves as an anticoagulant.

\subsection{Liver and kidney function tests}

The biochemical parameters, including the ALT, AST, and ALP, were estimated by ultraviolet, colorimetric, and spectrophotometric methods, respectively, as described by Bergneyer and Bernt [22]. The albumin and protein content were calculated by the biuret method as described by Parasuraman et al. [23].

For the determination of kidney functions, creatinine and urea levels were analyzed using the methods of Tietz [24]. The serum ions, including $\mathrm{Cl}^{-}, \mathrm{Na}^{+}$, and $\mathrm{K}^{+}$, levels were determined using the flame photometry method as described by Akhigbe et al. [25].

\subsection{Histopathological examination}

The liver tissues of the rats were prepared for histopathological examination using the method of Taylor et al. [26]. The tissues were excised and processed using routine hematoxylin and eosin staining techniques. Analysis of the tissues was done using qualitative methods with emphasis on the morphology, architectures, and cytological structures of the tissues.

\subsection{Data analysis}

Data were expressed as mean \pm standard error of mean (SEM). The statistical difference between the control and test groups was analyzed using Student's $t$ test. The value of $p \leq 0.05$ was considered significant.

\section{Results}

\subsection{Qualitative screening of the extracts}

Table 1 shows the results of qualitative analysis of extracts of the three plants. Of all the phytochemicals screened, only alkaloids, tannins, saponins, flavonoids, and glycosides were detected in the extracts.

\subsection{Quantitative screening of the extracts}

The results of quantitative analysis of the extracts of the three plants are presented in Table 2. Z. mauritiana has the highest concentration of alkaloids with $7.8 \%$, followed by $C$. occidentalis with $6.4 \%$, and the least was

Table 1 Phytochemicals detected in the methanol extracts of $Z$. mauritiana, C. occidentalis, and G. senegalensis

\begin{tabular}{llll}
\hline Phytochemical & Z. mauritiana & C. occidentalis & G. senegalensis \\
\hline Alkaloids & ++ & ++ & ++ \\
Tanins & ++ & ++ & + \\
Saponins & + & + & + \\
Flavonoids & + & + & + \\
Glycosides & + & + & + \\
Anthraquinones & - & - & - \\
Phlobatanins & - & - & - \\
Steroids & - & - & - \\
\hline
\end{tabular}

"++," present in abundance; "+," sparingly present; "-," not detected 
Table 2 Quantities of major phytochemicals detected in the methanol extracts of Z. mauritiana, C. occidentalis, and G. senegalensis

\begin{tabular}{llllll}
\hline Extract & Alkaloids (\%) & Tannins (\%) & Flavonoids (\%) & Saponins (\%) & Glycosides (\%) \\
\hline Z. mauritiana & 7.80 & 2.85 & 0.66 & 1.90 & 2.90 \\
C. occidentalis & 6.40 & 3.74 & 3.60 & 3.00 & 0.37 \\
G. senegalensis & 6.00 & 0.6 & 0.90 & 3.00 & 0.30 \\
\hline
\end{tabular}

G. senegalensis with $6.0 \%$. The highest level of tannins was detected in C. occidentalis with $3.74 \%$, while $2.84 \%$ and $0.6 \%$ were recorded in Z. mauritiana and G. senegalensis, respectively. The concentration of saponins in $Z$. mauritiana was $1.9 \%$, while $3.0 \%$ was found in both $C$. occidentalis and G. senegalensis. Glycoside content in $Z$. mauritiana was $2.9 \%$, while $0.37 \%$ and $0.3 \%$ were detected in C. occidentalis and G. senegalensis, respectively. The levels of flavonoids found in Z. mauritiana, C. occidentalis, and G. senegalensis are $0.66 \%, 3.6 \%$, and $0.9 \%$, respectively.

\subsection{Acute toxicities of the extracts}

Table 3 shows the reactions of the treated rats to the varied doses of the extracts of the three plants. Up to $2000 \mathrm{mg} \mathrm{kg}^{-1}$, the rats across the groups did not react negatively, while at $3000 \mathrm{mg} \mathrm{kg}^{-1}$, rats in the C. occidentalis group developed fatigue and breathing problem. At $5000 \mathrm{mg} \mathrm{kg}^{-1}$, the rats treated with $C$. occidentalis showed convulsion, while the rats administered with Z. mauritiana and G. senegalensis extracts showed weakness. There were no cases of death, indicating the $\mathrm{LD}_{50}$ of the extracts of the three plants are above $5000 \mathrm{mg} \mathrm{kg}^{-1}$.

\subsection{Effects of the extracts on liver enzymes}

Table 4 shows the effects of the plant extracts on the liver enzymes of the rats after 60-day dosing. Compared with the control (Fig. 1), significant differences ( $p<$ 0.05) were not observed in the levels of TP and ALB ( $g$ $\mathrm{dl}^{-1}$ ) of the rats administered Z. mauritiana, G. senegalensis, and $C$. occidentalis. However, the treated rats showed significant $(p<0.05)$ elevated levels of the ALP, AST, and ALT $\left(\mathrm{Ul}^{-1}\right)$.

\subsection{Effects of the extracts on the kidney function parameters}

The effects of 60-day dosing on the kidney functions of the rats are revealed in Table 5. The treated and control rats showed no significant difference $(p<0.05)$ in the levels of $\mathrm{Na}^{+}\left(\mathrm{mEq}{ }^{-1}\right), \mathrm{K}^{+}\left(\mathrm{mmoll}^{-1}\right)$, and $\mathrm{Cl}^{-}(\mathrm{mEq}$ $\mathrm{l}^{-1}$ ). However, significant differences exist between the treated and control rats in the levels of urea $\left(\mathrm{mg} \mathrm{dl}^{-1}\right)$ and creatinine $\left(\mathrm{ml} \mathrm{min}^{-1}\right)$.

\subsection{Histopathological effects of the extracts}

Figures 2, 3, and 4 describe the effects of the extracts on the liver tissues of the treated rats. Figures 2 and 3 are the liver sections of the rats administered G. senegalensis and Z. mauritiana, showing karyorrhexis, mild congestion, and lymphocytic infiltration. Fatty metamorphosis, inflammation, pyknotic-looking hepatocyte nuclei, and lymphocytic infiltration were observed in the liver sections of the rats treated with C. occidentalis (Fig. 4). No abnormalities were observed in the liver tissues of control rats (Fig. 1).

\section{Discussion}

The toxicity of the leaves of three medicinal plants, namely Z. mauritiana, C. occidentalis, and G. senegalensis, was established in this study. The study was initiated to prevent unintended fatalities among users of the medicinal plants in Nigeria and other parts of the world. Some phytochemicals, including alkaloids, tannins, glycosides, saponins, and flavonoids, were detected in the extracts of the plants (Tables 1 and 2), which indicate the plants could confer some health benefits. These bioactive substances are well known and reported in the literature for their health-boosting activities. The nonlethal property of the extracts across the groups at doses up to $5000 \mathrm{mg} \mathrm{kg}^{-1}$ (Table 3) shows the $\mathrm{LD}_{50}$ values of the

Table 3 Reactions of the rats to different doses of Z. mauritiana, C. occidentalis, and G. senegalensis

\begin{tabular}{lllll}
\hline Extract & \multicolumn{2}{l}{ Doses $\left(\mathrm{mg} \mathrm{kg}^{-1}\right)$ administered for 3 days } & \multicolumn{2}{l}{3000} \\
\cline { 2 - 4 } & 500 & 1000 & $\mathrm{Nil}$ & $\mathrm{Nil}$ \\
\hline Z. mauritiana & $\mathrm{Nil}$ & $\mathrm{Nil}$ & $\mathrm{Nil}$ & Weakness and gasping for breath \\
C. occidentalis & $\mathrm{Nil}$ & $\mathrm{Nil}$ & $\mathrm{Nil}$ & $\mathrm{Nil}$ \\
G. senegalensis & $\mathrm{Nil}$ & $\mathrm{Nil}$ & $\mathrm{Nil}$ \\
Control & $\mathrm{Nil}$ & $\mathrm{Nil}$ & Weakness \\
\hline
\end{tabular}


Table 4 Liver enzymes of the rats dosed with Z. mauritiana, C. occidentalis, and G. senegalensis

\begin{tabular}{lllll}
\hline Parameter & Control & Z. mauritiana & G. senegalensis & C. occidentalis \\
\hline TP $\left(\mathrm{g} \mathrm{dl}^{-1}\right)$ & $07.23 \pm 0.3^{\mathrm{a}}$ & $06.93 \pm 0.4^{\mathrm{a}}$ & $7.13 \pm 0.1^{\mathrm{a}}$ & $06.90 \pm 0.2^{\mathrm{a}}$ \\
ALB $\left(\mathrm{g} \mathrm{dl}^{-1}\right)$ & $04.11 \pm 0.2^{\mathrm{a}}$ & $04.05 \pm 0.1^{\mathrm{a}}$ & $4.10 \pm 0.6^{\mathrm{a}}$ & $04.03 \pm 0.6^{\mathrm{a}}$ \\
ALP $\left(\mathrm{U} \mathrm{I}^{-1}\right)$ & $24.00 \pm 2.6^{\mathrm{a}}$ & $13.00 \pm 1.7^{\mathrm{b}}$ & $11.33 \pm 1.5^{\mathrm{b}}$ & $13.01 \pm 2.9^{\mathrm{b}}$ \\
AST $\left(\mathrm{U} \mathrm{I}^{-1}\right)$ & $86.67 \pm 10^{\mathrm{a}}$ & $160.33 \pm 15.60^{\mathrm{b}}$ & $194.33 \pm 16.60^{\mathrm{b}}$ & $191.67 \pm 5.61^{\mathrm{b}}$ \\
ALT $\left(\mathrm{U} \mathrm{I}^{-1}\right)$ & $53.33 \pm 3.5^{\mathrm{a}}$ & $41.67 \pm 3.40^{\mathrm{b}}$ & $100.66 \pm 9.26^{\mathrm{b}}$ & $67.33 \pm 1.76^{\mathrm{a}}$
\end{tabular}

Values were expressed as mean $\pm \mathrm{SE}$; number of rats per group $(n)=6$; statistical test $=$ Student's $t$ test; values along the row with different superscript letters as the control are statistically different from control at $p<0.05$

methanol extracts of the plants were within the standard range of $500-5000 \mathrm{mg} \mathrm{kg}^{-1}$ body weight proposed by Lorke [27]. Hence, a single oral administration of the plants less than or equal $5000 \mathrm{mg} \mathrm{kg}^{-1}$ is not expected to cause any fatality. However, as noticed in the reactions of the rats, a single oral dose of $3000 \mathrm{mg} \mathrm{kg}^{-1}$ for $Z$. mauritiana and G. senegalensis as well as $2000 \mathrm{mg} \mathrm{kg}$ for C. occidentalis is advisable. The fatigue and convulsion displayed by some of the rats between 3000 and 5000 $\mathrm{mg} \mathrm{kg}^{-1}$ could be the effects of one or more of the phytochemicals in the extracts, particularly alkaloids, tannins, and saponins.

The reduction in the metabolic enzymes (TP, ALB) as well as the increase in other liver enzymes (ALP, AST, ALT) of the rats after 60-day dosing (Table 4) is symptomatic of the presence of cytotoxic agents. The changes were particularly more pronounced in the rats dosed with $Z$. muritiana and $C$. ccidentalis, both of which contain relatively high tannins and alkaloids. Similar patterns were also observed in the reduction of kidney function parameters $\left(\mathrm{Na}^{+}, \mathrm{K}^{+}, \mathrm{Cl}^{-}\right.$, urea, creatinine) of the rats at the end of the dosing period (Table 5). The changes in these health indices could result from the gradual accumulation of certain substances in

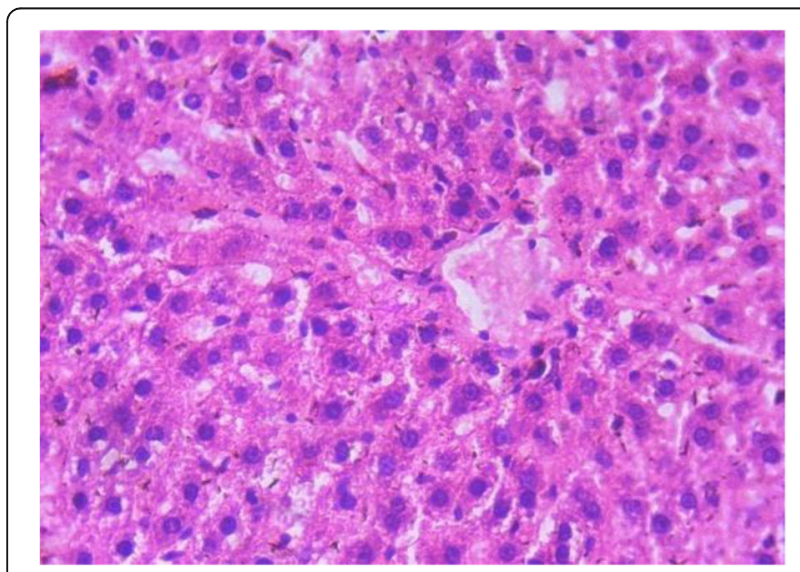

Fig. 1 Photomicrograph of the liver section of the control rats showing no abnormality $(\times 40)$ the extracts to toxic levels in the blood of the treated rats. Though any bioactive substance, both tested and non-tested in the studied extracts, could have caused these changes, the primary suspects in this study are tannins and alkaloids detected in moderate abundance in the extracts. Several studies have reported toxicities of alkaloids and tannins in animals following a prolonged treatment. For instance, alkaloids derived from

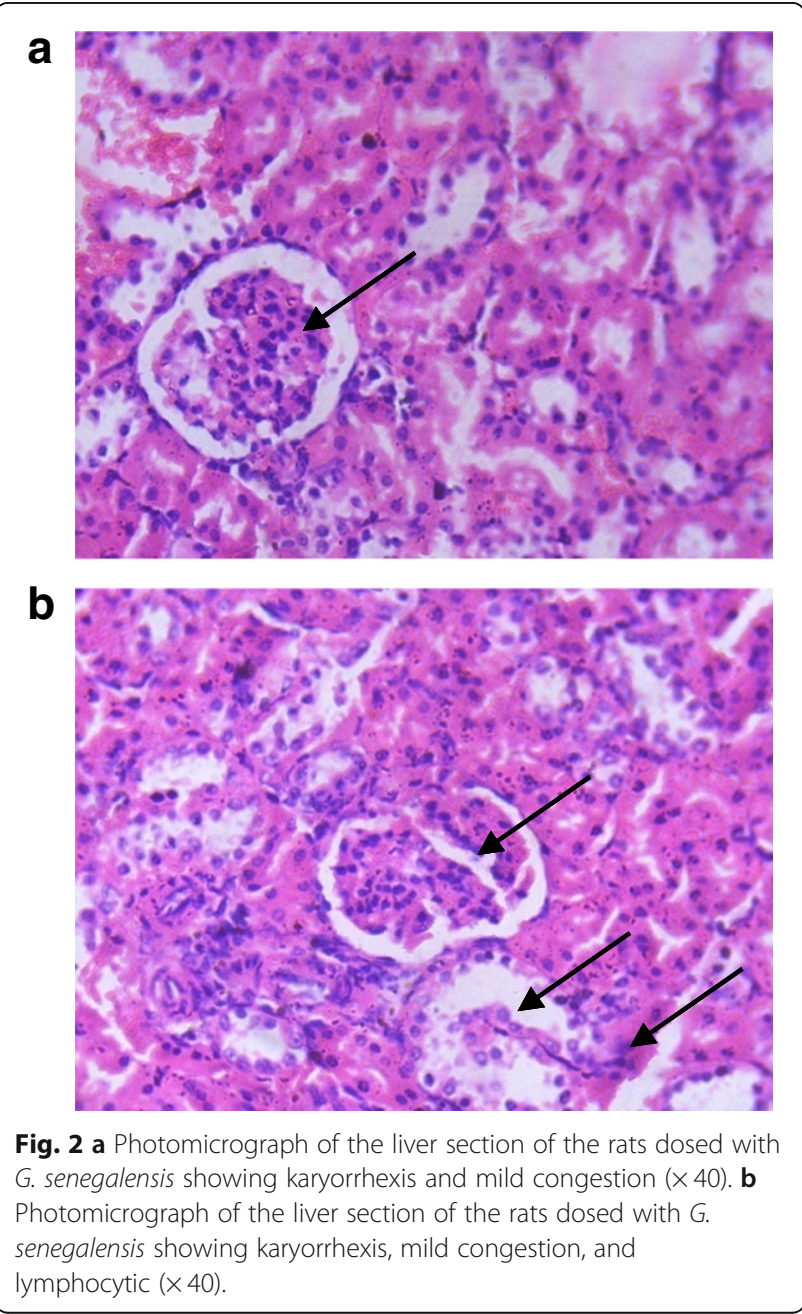


Table 5 Kidney parameters of the rats treated with Z. mauritiana, C. occidentalis, and G. senegalensis

\begin{tabular}{|c|c|c|c|c|}
\hline Parameter & Control & Z. mauritiana & G. senegalensis & C. occidentalis \\
\hline$\overline{\mathrm{Na}^{+}\left(\mathrm{mEq} \mathrm{I}^{-1}\right)}$ & $139.67 \pm 10.3^{a}$ & $139.00 \pm 10.5^{a}$ & $139.67 \pm 10.3^{a}$ & $140.33 \pm 11.8^{a}$ \\
\hline $\mathrm{K}^{+}\left(\mathrm{mmol} \mathrm{I} \mathrm{l}^{-1}\right)$ & $4.90 \pm 0.5^{a}$ & $4.33 \pm 0.9^{a}$ & $4.43 \pm 0.2^{a}$ & $4.13 \pm 0.2^{a}$ \\
\hline $\mathrm{Cl}^{-}\left(\mathrm{mEq} \mathrm{I}^{-1}\right)$ & $107.00 \pm 5.8^{a}$ & $101.00 \pm 6.8^{a}$ & $102.67 \pm 4.9^{a}$ & $102.67 \pm 5.1^{\mathrm{a}}$ \\
\hline Urea $\left(m g d^{-1}\right)$ & $4.87 \pm 0.3^{\mathrm{a}}$ & $4.07 \pm 0.9^{b}$ & $4.38 \pm 0.3^{b}$ & $4.00 \pm 0.6^{b}$ \\
\hline Creatinine $\left(\mathrm{ml} \mathrm{min}^{-1}\right)$ & $68.00 \pm 3.8^{\mathrm{a}}$ & $54.68 \pm 3.7^{b}$ & $54.33 \pm 5.8^{b}$ & $47.00 \pm 4.5^{b}$ \\
\hline
\end{tabular}

Values were expressed as mean $\pm \mathrm{SE}$; number of rats per group $(n)=6$; statistical test $=$ Student's $t$ test; value along the row with different superscript letters as the control are statistically different from control at $p<0.05$

the bark of Yohimbe tree have been reported to alter liver and kidney function parameters of rats administered $14 \mathrm{mg} \mathrm{kg}^{-1}$ dose for 15 days [28]. Tannins extracted from a plant had also been reported to induce changes in the liver enzymes of some rats administered $2.5 \mathrm{mg} \mathrm{ml}^{-1}$ doses [29].

Additionally, the changes observed in the liver and kidney function parameters are indicative of liver toxicity or injury [30]. According to Herrine [31], some medicinal herbs contain substances that can damage

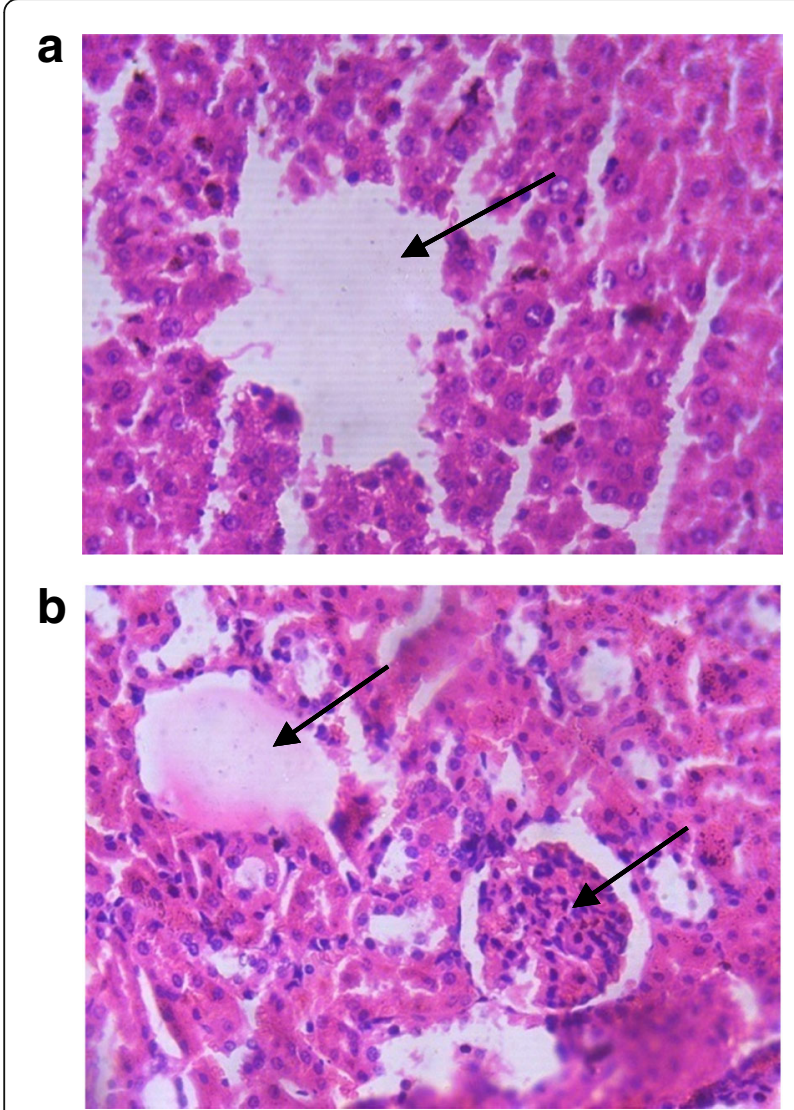

Fig. 3 a Photomicrograph of the liver section of the rats dosed with Z. mauritiana showing karyolysis and mild congestion within the central vein $(\times 40)$. $\mathbf{b}$ Photomicrograph of the liver section of the rats dosed with $Z$. mauritiana showing karyolysis and lymphocytic infiltration $(\times 40)$ the liver. The liver is the primary target of toxins because it processes all substances ingested. The deteriorating state of the liver tissues of the treated rats is evident in their histological sections, which showed karyorrhexis, mild congestion, lymphocytic infiltration, fatty metamorphosis, inflammation, and pyknoticlooking hepatocyte nuclei. These effects were more pronounced in $C$. occidentalis and $Z$. mauritiana groups-the same pattern observed in the kidney and liver function tests.

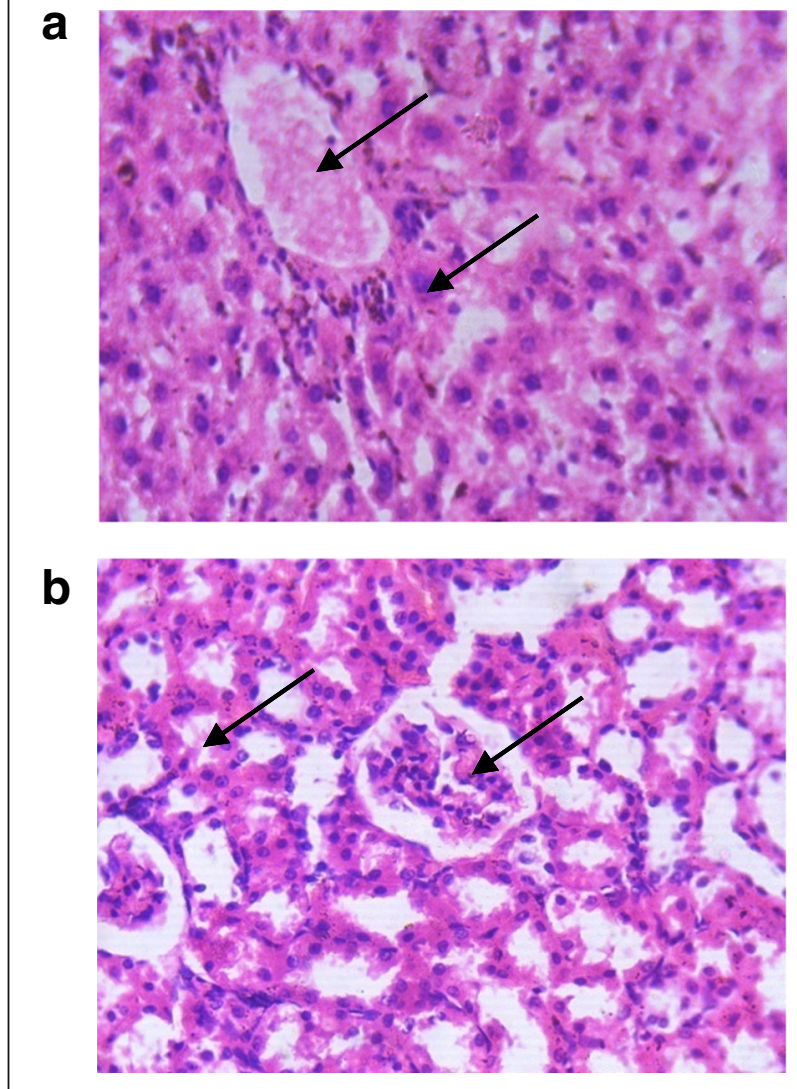

Fig. 4 a Photomicrograph of the liver section of the rats dosed with C. occidentalis showing fatty metamorphosis $(\times 40)$. $\mathbf{b}$ Photomicrograph of the liver section of the rats dosed with $C$. occidentalis showing inflammation, lymphocytic infiltration, and pyknotic-looking hepatocyte nuclei $(\times 40)$ 
Generally, many medicinal plants are safe, but eating a large amount of one type of green plant, over time, could lead to health issues. Phytochemical poisoning, such as alkaloid and tannin poisoning, can occur from consumption of any specific type of green vegetable over an extended period [32].

\section{Conclusion}

The findings of this study show the plants are rich in health-boosting bioactive substances that are pharmacologically safe in moderate doses. However, repeatedly consuming the plants for an extended period could be harmful to health. Some phytochemicals detected in the plants, particularly alkaloids and tannins, could bioaccumulate in the blood to toxic levels and cause health issues, including liver and kidney problems.

\section{Abbreviations}

ALB: Albumin; ALP: Alkaline phosphatase; ALT: Alanine aminotransferase; AST: Aspartate aminotransferase; $\mathrm{Cl}^{-}$: Chloride ion; $\mathrm{K}^{+}$: Potassium ion; $\mathrm{Na}^{+}$: Sodium ion; TP: Total protein

\section{Acknowledgements}

We are grateful to Prof. MDA Bunza, Department of Biology, Federal University Birnin Kebbi, Nigeria, for his effort in securing the grant.

\section{Authors' contributions}

TY conceptualized, designed, and drafted the manuscript; did the correspondence; and coordinated all the experiments. KS provided mentorship and carried out the qualitative and quantitative analysis of the extracts, while HN collected the plant materials, provided the rats, and conducted the kidney function test. EO carried out the histopathological studies and revised the manuscript, while US did the liver function test and participated in drafting the article. All authors read and approved the final manuscript

\section{Funding}

This study was supported by a grant from the Tertiary Education Trust Fund (TETFUND), Nigeria (FUBK/2016/BATCH4 RP/2).

The fund covered the entire study, including the design, data collection, experimentation, and analysis and interpretation of data as well as manuscript writing.

\section{Availability of data and materials}

All data generated or analyzed during this study are included in this published article.

\section{Ethics approval and consent to participate}

This study was conducted with the approval of the Animal Ethics Committee of Federal University Birnin Kebbi, Nigeria. The Guide of Care and Use of Animals in Research and Teaching as outlined by the committee was used to manage the animals.

\section{Consent for publication}

Not applicable

\section{Competing interests}

The authors declare that they have no competing interests.

\section{Author details}

1Department of Biology, Federal University Birnin Kebbi, Birnin Kebbi PMB 1157, Nigeria. Biology Unit, Distance Learning Institute, University of Lagos, Lagos, Nigeria. ${ }^{3}$ Department of Biochemistry and Molecular Biology, Federal University Birnin Kebbi, Birnin Kebbi, Nigeria.
Received: 24 June 2019 Accepted: 1 October 2019

Published online: 28 November 2019

\section{References}

1. Silva O, Gomes ET (2003) Guieranone A, a naphthylbutenone from the leaves of Guiera senegalensis with antifungal activity. J Nat Prod 66:447-449. https://doi.org/10.1021/np0204904

2. Silva O, Serrano R, Gomes ET (2008) Botanical characterization of Guiera senegalensis leaves. Microsc Microanal 14:398-404. https://doi.org/10.1017/ S1431927608080860

3. Oyebode O, Kandala N-B, Chilton PJ, Lilford RJ (2016) Use of traditional medicine in middle income countries: a WHO-SAGE study. Health Policy Plan 31:984-991. https://doi.org/10.1093/heapol/czw022

4. Beyene B, Belachew B (2016) Habitamu D (2016). Review on application and management of medicinal plants for the livelihood of the local community. J Resour Dev Manag 22:33-39

5. Houghton PJ (1995) The role of plants in traditional medicine and current therapy. Journal of Alternative and Complementary Medicine 1(2):131-143. https://doi.org/10.1089/acm.1995.1.131

6. Mahomoodally MF (2013) Traditional medicines in africa: an appraisal of ten potent african medicinal plants. Evid Based Complement Alternat Med: e617459. https://doi.org/10.1155/2013/617459

7. Fiot J, Sanon S, Azas N, Mahiou V, Jansen O, Angenot L, Balansard G, Ollivier E (2006) Phytochemical and pharmacological study of roots and leaves of Guiera senegalensis J.F. Gmel (Combretaceae). Journal of ethnopharmacology 106:173-178. https://doi.org/10.1016/j.jep.2005.12.030

8. Shellar DB, Shirote PJ (2011) Natural product in drug discovery: back to future. Biomed Pharmacol J 4:141-146

9. Kankara SS, Ibrahim MH, Mustafa M, Go R (2018) Ethnobotanical survey of medicinal plants used for traditional maternal healthcare in Katsina state, Nigeria. South African J Bot 97:165-175. https://doi.org/10.1016/j. sajb.2015.01.007

10. Ene AC, Arawodi SE (2012) Ethnomedicinal survey of plants used by the Kanuris of Northeastern Nigeria. Indian J Tradit Knowl 4:640-645

11. Nuhu AA, Aliyu R (2008) Effects of Cassia occidentalis aqueous leaf extract on biochemical markers of tissue damage in rats. Trop J Pharm Res 7(4): 1137-1142

12. Sadiq IS, Shuaibu M, Bello AB, Tureta SG, Isah A, Izuagie T, Nasiru S, Kamaru MB (2012) Phytochemistry and antimicrobial activities of Cassia occidentalis used for herbal remedies. J Chem Eng 1(1):38-41

13. Najafi S (2013) Phytochemical screening and antibacterial activity of leaf extract of Ziziphus mauritiana Lam. Int Res J Appl Basic Sci 4(10):3274-3276

14. Dahiru D, Sini JM, John-Africa L (2006) Antidiarrhoeal activity of Ziziphus maritiana root extract in rodent. Afr J Biotechnol 5(10):941-945

15. Silva MG, Aragão TP, Vasconcelos CF, Ferreira PA, Andrade BA, Costa IM, Costa-Silva JH, Wanderley AG, Lafayette SS (2011) Acute and subacute toxicity of Cassia occidentalis L. stem and leaf in Wistar rats. J Ethnopharmacol 136(2):341-346. https://doi.org/10.1016/j.jep.2011.04.070

16. Vashishtha VM, Kumar AT, John J, Nayak NC (2007) Cassia occidentalis poisoning as the probable cause of hepatomyoencephalopathy in children in western Uttar Pradesh. Indian J Med Res 125:756-762

17. Sofowora A (1993) Medicinal plants and traditional medicine in Africa. Spectrum Books Ltd., Ibadan, Nigeria, pp 191-289

18. Ajuru MG, Williams LF, Ajuru G (2017) Qualitative and quantitative phytochemical screening of some plants used in ethnomedicine in the Niger Delta Region of Nigeria. J Food Nutr Sci 5(5):198-205. https://doi.org/ 10.11648/j.jns.20170505.16

19. Trevan JW (1927) The error of determination of toxicity. Proc Royal Soc London B 101(712):480-514. https://doi.org/10.1098/rspb.1927.0030

20. Almeida RN (2006) Psicofarmacologia: fundamentos práticos. Guanabara Koogan, Rio de Janeiro, Brasil

21. Hugo SM, Russel AO (1984) Antimicrobial activities of some African medicinal plant. J Chem Soc Nigeria 15:351-360

22. Bergneyer HU, Bernt E (1974). In: method of enzymatic analysis; Berdnery, H. U. 2nd ed., Academic press, New York, Pp 574-579.

23. Parasuraman $S$, Raveendran $R$, Kesavan $R$ (2010) Blood sample collection in small laboratory animals. J Pharmacol Pharmacother 1:87-93. https://doi. org/10.4103/0976-500X.72350

24. Tietz NW (1994) Textbook of clinical chemistry. $2^{\text {nd }}$ ed. Saunders Company, Philadelphia: W.B, p 1919. https://doi.org/10.1016/0307-4412(86)90182-2 
25. Akhigbe RE, Ige SF, Afolabi AO, Oyeyipo PI, Ajao FO, Ajayi FA (2008) Water balance and serum levels of some electrolytes in oral contraceptive-treated female wistar rats. J Med Sci 8:591-594. https://doi.org/10.3923/jms.2008. 591.594

26. Taylor DJ, Green NP, Stout GW (2003) Microscope techniques. Biological Science, 3rd edn. Cambridge University Press, U. K., pp 163-164

27. Lorke D (1983) A new approach to practical acute toxicity testing. Arch Toxicol 54:275-287. https://doi.org/10.1007/BF01234480

28. Yakubu MT, Bilbis LS, Lawal M, Akanji MA (2003) Evaluation of selected parameters of rat liver and kidney function following repeated administration of yohimbine. Biochemistry 15:50-56

29. Vejayan J, Jamunaa A, Halijah I (2016) Adverse effects of tannin contained in Mimosa pudica root extract. J Appl Sci 16:477-483. https://doi.org/10.3923/ jas.2016.477.483

30. Reuben A (2004) Hy's law. Hepatology 39:574-578. https://doi.org/10.1002/ hep. 20081

31. Herrine SK (2018). Medicinal herbs and the liver. Available online at https:// www.merckmanuals.com/home/liver-and-gallbladder-disorders/drugs-andthe-liver/liver-injury-caused-by-drugs. (Accessed 1 Nov 2018).

32. Sara O (2018). Alkaloid poisoning: symptoms \& treatment. Available online at https://study.com/academy/lesson/alkaloid-poisoning-symptomstreatment.html (Accessed 28 Dec 2018)

\section{Publisher's Note}

Springer Nature remains neutral with regard to jurisdictional claims in published maps and institutional affiliations.

\section{Submit your manuscript to a SpringerOpen ${ }^{\odot}$ journal and benefit from:}

- Convenient online submission

- Rigorous peer review

- Open access: articles freely available online

- High visibility within the field

- Retaining the copyright to your article

Submit your next manuscript at $\boldsymbol{\nabla}$ springeropen.com 